\title{
There Must Be Some Way Out of Here...The Crisis, Labour Rights and Member States in the Eye of the Storm
}

\author{
Eftychia Achtsioglou* and Michael Doherty*
}

\section{Abstract}

This article considers the impact of the economic, social and political crisis on the labour law regimes of two of the Member States of the European Union most affected; Greece and Ireland. Both countries have been the recipients of 'bail-out' deals, negotiated and monitored by what has become known as the 'Troika' of the European Commission, the European Central Bank and the International Monetary Fund. The article considers the extent to which both countries have been required to make amendments to their labour law regimes, as a condition of their bail-outs. It argues that the changes demanded reflect the basic norm now governing the EU legal order, namely that of 'competition'; the logic of market integration based on the primacy of economic competition.

\section{Introduction}

In 2004, the project of European Union integration was convulsed by the shock of referendum defeats in France and the Netherlands, when the proposed Constitutional Treaty was rejected. From today's viewpoint, the periods of institutional and existential 'crisis' that followed that rejection, and the protracted and difficult negotiations that led to the signing of the Treaty of Lisbon, ${ }^{1}$ which came into force in December 2009, seem almost like halcyon days. The economic, social and political crisis that has erupted since 2008 has thrown the very survival of the European project into doubt. $^{2}$

This article considers specific impacts of the crisis in the context of two of the Member States in the eye of the storm. Greece and Ireland were the first two Eurozone Member States to require a funding package (commonly referred to as a 'bail-out') from the 'Troika' of the European Commission, the European Central Bank

\footnotetext{
* School of Law, Faculty of Law, Economic and Political Sciences, Aristotle University of Thessaloniki, Greece. Email: eachtsio@law.auth.gr

* School of Law and Government, Dublin City University, Dublin 9, Ireland. Email:

Michael.doherty@dcu.ie.

'P. Craig, 'The Treaty of Lisbon, Process, Architecture and Substance', (2008) 33(2) European Law Review 137; P. Syrpis, 'The Treaty of Lisbon: Much Ado...but about what?', (2008) 37(3) Industrial Law Journal 219.

2 M. Ruffert, 'The European Debt Crisis and European Union Law', (2011) 48 Common Market Law Review 1777, 1777.
} 
(ECB) and the International Monetary Fund (IMF). As part of the conditions for receiving funding, both countries agreed Memorandums of Understanding (MoUs) with the Troika, under the terms of which each has pledged to undertake specified legal, economic and political reforms. It is the reforms required of each country's collective labour law regimes with which this article is concerned. An analysis of these will demonstrate a clear norm underlying the approach of the Troika to regulation of the labour markets in the two States. We will argue that this norm is also evident in recent case law of the Court of Justice of the EU (CJEU) in relation to the vexed question of the balance between fundamental labour rights and worker protection, on the one hand, and the free movement of services and rights of establishment, on the other. We will argue that both recent decisions of the CJEU, and the labour market changes the Troika is insisting be made in Greece and Ireland, clearly demonstrate the existence of a hierarchical relationship in which fundamental labour rights are subordinated to fundamental economic freedoms. We will argue that the construction of this hierarchy has profound implications for the social dimension of the European integration project.

The article proceeds as follows. First, we briefly outline how the crisis has played out in Greece and Ireland and sketch the background to the necessity of the Troika stepping in to bail-out the two countries. We then examine the labour market reform measures required by the Troika (focusing on those relating to collective autonomy, trade union rights, and arbitration and wage-setting mechanisms) before moving on to analyse the legislative reforms introduced or promised by both governments. We go on to critique the rationale underlying the reforms demanded, setting this in the context of what we see to be the basic norm governing the EU legal order as it has been established by the EU institutions and developed by the CJEU, namely that of 'competition'. We conclude by reflecting on the implications of these developments for the future of EU activity in the area of labour rights and the broader social policy field.

\section{The Crisis}

Much ink has already been spilled in describing and analysing the origins and development of what has become known, simply, as 'the crisis'. ${ }^{3}$ We do not propose to cover this ground again here, but merely to briefly set the context for the signing of the MoUs in Greece and Ireland. This will involve a brief outline of the Greek and Irish industrial relations and labour law models and a description of how both countries came to the brink of economic collapse.

\footnotetext{
${ }^{3}$ See, for example, J.V. Louis, 'Guest Editorial: The No-Bailout Clause and Rescue Packages' (2010) 47 Common Market Law Review 971; K. Featherstone, 'The Greek Sovereign Debt Crisis and EMU: A Failing State in a Skewed Regime' (2011) 49(2) Journal of Common Market Studies 193; and the special issue 'Collective Bargaining, Trade Unions and the Crisis' (2011) 17(3) Transfer: European Review of Labour and Research 303-403.
} 


\section{A. Greece}

Since the enactment of law 1876/1990, the Greek system of employment relations has become increasingly decentralised, involving a complex interaction between different sources of labour rights. A general framework of minimum obligatory working conditions is set out in legislation. ${ }^{4}$ However, after setting this general framework, the State is expected to retreat and respect the 'collective autonomy' of the social partners. ${ }^{5}$ Collective autonomy refers to the right of workers' and employers' representative bodies to negotiate collectively, and to define jointly, the terms and conditions of employment, as well as to resort to arbitration in the event that negotiations fail. A particular feature of Greek labour law is that collective autonomy is protected by Article 22(2) of the Greek Constitution, which prohibits State intervention both in the bargaining procedure, and in the content of collective agreements (CAs) and arbitration awards. The relationship between statutes and CAs is governed by the so-called 'favourability principle', according to which any terms contained in a CA which are more favourable to workers prevail over the terms set by legislation. ${ }^{6}$

Pursuant to law 1876/1990, there are five types of collective agreements in Greece:

(1) National multi-industry agreements, called National General Collective Agreements (NGCAs); (2) Industry-wide sectoral agreements; (3) Enterprise-level agreements; (4) Occupational agreements at national level; and (5) Occupational agreements at local level. The NGCAs are concluded annually or biennially between the Greek General Confederation of Labour (the main national trade union confederation), on the one hand, and the Federation of Greek Industries and General Confederation of Greek Small Businesses and Trades, on the other. Consequently, the social partners - and not the State - are responsible for fixing the obligatory minimum levels of pay and other working conditions that are applied throughout Greece.

All collective agreements reached through collective bargaining are directly binding. The NGCAs and the enterprise-level CAs apply erga omnes, so that their normative terms become an integral part of any individual employment contract, which falls within their scope of application, while the sectoral and occupational-level CAs are binding only on the members of unions which have subscribed to these agreements. ${ }^{7}$ However, the terms of an individual employment contract can prevail over the terms of the relevant CA where the former are more favourable to the employee than the latter, according to the favourability principle. ${ }^{8}$ Until the recent

\footnotetext{
${ }^{4}$ G. Lyon-Caen, J. Pélissier, and A. Supiot, Droit du Travail (Dalloz, 17e éd., 1994$), 37$.

${ }^{5}$ A. Kazakos, Collective Labour Law (Sakkoulas, 2009) [in Greek], 54. The Supreme Administrative Court of Greece has also accepted this distribution of roles between the State and social partners; Council of State 632/1978, (1978) The Constitution, 178 [in Greek].

${ }^{6}$ N. Aliprantis, La Place de la Convention Collective de Travail dans la Hiérarchie des Normes (LGDJ, 1980), 52-65.

${ }^{7}$ I. Koukiadis, Labour Law: Collective Employment Relations (Sakkoulas, 2nd edn, 2011) [in Greek], 293-298.

${ }^{8}$ G. Lyon-Caen, J. Pélissier, and A. Supiot, op cit n 4 supra, 49.
} 
changes discussed below, the favourability principle governed not only the relationship between individual employment contracts and CAs, but also the articulation of the different types of CAs. ${ }^{9}$ In line with this principle, a lower level CA (e.g. a local-level occupational agreement) could prevail over a higher level one (e.g. a sectoral agreement), where the former guaranteed more favourable terms to the employee than the latter.

\section{i. The Greek Crisis}

For the past three years, Greece has been lying at the epicentre of a global and European crisis, ${ }^{10}$ which started as a financial crisis, turned into a sovereign debt crisis followed by a crisis in the real economy, ${ }^{11}$ and now manifests itself as a deep social crisis with major impacts on the labour market. In May 2010, while the Eurozone failed to address the private debt crisis - which, along with the sovereign debt emergency, form the two components of the economic crisis - ${ }^{12}$ the Greek government announced the country's accession to an EU-IMF support mechanism in order to confront the high budget deficit and growing public debt. As a condition of receiving the EU-IMF loans, Greece was expected to implement not only severe fiscal cuts (an immediate 10\% cut to government spending), but also extensive structural reforms. The terms of the First Memorandum of Understanding agreed with the Troika demanded a package of emergency measures, including pay cuts for all public servants and restrictions on pension rights, and resulted in lay-offs in both the public and private sectors. Unsurprisingly, in the eyes of many commentators, these austerity measures, instead of reducing the high deficit, served only to constrain economic activity even further, with the country's economy sinking into a deeper recession. ${ }^{13}$

Nevertheless, the Greek government announced at the end of 2010 new, tougher austerity measures, new taxes, and a higher rate of VAT. Once again, the imposed measures accompanied only a worsening of the country's debt. By the summer of 2011 , it became clear that debt restructuring was unavoidable. ${ }^{14}$ After the Greek

\footnotetext{
9 ibid, 784.

${ }^{10}$ See E. Tsakalotos, 'Contesting Greek Exceptionalism: The Political Economy of the Current Crisis', in K. Featherstone (eds), Europe in Modern Greek History (Columbia University Press, forthcoming), where the author argues that, as the current crisis results precisely from the application of the neoliberal economic project, the Greek case does not stand out as an exception.

${ }^{11}$ For a thorough and comprehensive analysis of the contemporary economic crisis and its origins see Y. Varoufakis, The Global Minotaur: America, the True Origins of the Financial Crisis and the Future of the World Economy (Zed Books, 2011).

12 ibid.

${ }^{13}$ Y. Varoufakis, 'Viewpoint: Greece's Austerity Measures Doomed to Fail', article at BBC News, available at http://www.bbc.co.uk/news/world-europe-11818910 (accessed 21 May 2012).

${ }^{14}$ See J. Milios and D. Sotiropoulos, 'Crisis of Greece or Crisis of the Euro? A View from the European "Periphery"' (2010) 12(3) Journal of Balkan and Near Eastern Studies 223, where the authors, arguing in 2010 that debt restructuring was already unavoidable, set the rhetorical question: 'If the debt is going to be renegotiated finally to the figure of 50 per cent, why do we have to go through the stage of recession, high unemployment, income deflation and the dismantling of all of working people's rights?', at 239.
} 
Private Sector Involvement (PSI) was announced in July 2011, and without any national elections being held, a new coalition government came to power with the support of Greece's two largest political parties (PASOK and New Democracy) and the participation of the far-right party, LAOS. The new government committed to carrying out the terms of the new bail-out-PSI combination package. However, the deep 'haircut' carried out in October 2011 was accompanied by a new loan and a new agreement on another austerity plan. The new package of austerity measures signed between the Greek government and Troika in February 2012, widely known as the 'Second Memorandum', found Greece's workforce bearing the cost of the 'voluntary default', Greece facing a shrinking economy and a still unsustainable debt, and Europe facing the extension of the crisis into an indefinite future. At the time of writing, Greece is preparing for new elections to be held in June 2012, since the efforts to form a new coalition government following the general election held on 6 May have failed, thus prolonging the country's political crisis.

\section{B. Ireland}

The Irish tale is similarly cautionary. The Irish system of employment relations has traditionally been classified as 'voluntarist', where the role of the State is primarily to provide a supportive framework for collective bargaining (rather than to regulate the labour market by way of legislation). ${ }^{15}$ Whilst, in the last two decades, a number of developments, notably the decline in trade union density and workplace presence since the 1980s and the obligations of EU membership, has resulted in a large volume of labour legislation being passed, the vast majority of legislative measures provides for rights in respect of individual workers. ${ }^{16}$ In terms of collective labour law, voluntarism, in the Irish context, refers to a situation whereby employees have a constitutional right to form trade unions, but employers are under no obligation to bargain with such unions. ${ }^{17}$ There is, furthermore, no statutory recognition scheme under which employers can, in certain circumstances, be mandated to recognise trade unions for bargaining purposes.

Where collective bargaining does take place, collective agreements reached have generally been regarded under Irish law as not being capable of legal enforcement. ${ }^{18}$ Moreover, concluded collective agreements do not produce erga omnes effects. Certain limited exceptions to this general rule exist, such as where collective agreements are registered with the Labour Court (known as Registered Employment Agreements; REAs). ${ }^{19}$ Collective agreements made by Joint Industrial Councils

\footnotetext{
${ }^{15}$ R. Hyman, 'Industrial Relations in Europe: Theory and Practice', (1995) 1(1) European Journal of Industrial Relations 17.

${ }^{16}$ M. Doherty, 'Developments in Legal Scholarship: Labour Law', in T. Mohr and J. Schweppe (eds) 30 Years of Legal Scholarship (Thomson Round Hall, 2011), at 274, 281.

${ }_{17}^{17}$ A. Kerr and G. Whyte, Irish Trade Union Law (Professional Books Limited, 1985), 15.

18 Goulding Chemicals Ltd. v Bolger [1977] IR 211.

${ }^{19}$ Part III of the Industrial Relations Act 1946. The Labour Court, despite its moniker, is not a court of law, but an employment tribunal, made up of an independent chair and representatives of the social partners; in recent years it has increasingly been granted powers to make legally binding determinations in a range of areas; see M. Doherty, 'Institutional Challenge: Tribunals, Industrial Relations and the Law', (2009) 2 Employment Law Review 70.
} 
(JICs) are also registered with the Labour Court and are legally binding. ${ }^{20} \mathrm{JICs}$ are voluntary negotiating bodies for an industry or part of an industry, designed to facilitate collective bargaining at industry level; they generally exist in sectors with relatively high levels of unionisation (e.g. the construction sector). In practice, sectoral REAs are made between the main employer body representing employers in the sector and the trade unions representing workers in the industry. In addition, Joint Labour Committees (JLCs) provide for the fixing of minimum rates of pay and the regulation of employment in certain sectors where there is little or no collective bargaining and where significant numbers of vulnerable workers are employed (e.g. retail, catering and hotels). ${ }^{21} \mathrm{JLCs}$, which comprise of an independent chairperson, appointed by the Minister, and representative members of workers and employers, propose Employment Regulation Orders (EROs), which, when confirmed by the Labour Court, set legally binding minimum wages and conditions of employment for workers in the sectors covered. Prior to 2011, EROs provided: for minimum sectoral rates of pay in excess of the national minimum wage; for sectoral pay scales, based on length of service and skill level; for sectoral overtime payments and premium payments to those required to work on Sundays; and for benefits for employees in the relevant sectors that were not imparted by general labour legislation (most notably, a right to sick pay).

From 1987-2009, a series of tripartite social pacts was concluded between the social partners (the State, unions, employers and some other representative interest groups), focusing on issues of pay (particularly in the public sector), tax reform and a range of other socio-economic issues. ${ }^{22}$ Again, the bargaining and implementation processes under the 'social partnership' process were voluntary, with unilateral withdrawal by any party possible at any time. A number of measures were agreed, which were then progressed through the normal legislative process; for example, legislation on the national minimum wage. ${ }^{23}$ The Irish social partnership model attracted a wave of attention from academics and policy-makers all over the world, ${ }^{24}$ which focused on how Ireland, with its historically antagonistic, fragmented AngloSaxon industrial relations system, was capable of maintaining such a distinctive, corporatist-style system of socio-economic governance. Furthermore, the social partnership era coincided with the 'Celtic Tiger' period of astonishing growth in wealth creation and employment. ${ }^{25}$

\section{i. The Irish Crisis}

The crisis that has gripped most of the Western world has, however, brought the Irish social partnership juggernaut crashing to a halt and Ireland is presently in the

\footnotetext{
${ }^{20}$ Part V of the Industrial Relations Act 1946.

${ }^{21}$ Part IV of the Industrial Relations Act 1946.

22 See M. Doherty, 'It Must Have Been Love...But It's Over Now: The Crisis and Collapse of Irish Social Partnership' (2011) 17(3) Transfer: European Review of Labour and Research 371.

${ }^{23}$ The National Minimum Wage Act 2000.

${ }^{24}$ See, for example, P. Auer, Employment Revival in Europe (ILO, 2000); L. Baccaro, 'The Constitution of "Democratic" Corporatism in Italy', (2002) 30(2) Politics and Society 327.

${ }^{25}$ P.J. O'Connell, Astonishing Success-Economic Growth and the Labour Market in Ireland (ILO, 2000).
} 
grip of a deep economic recession. ${ }^{26}$ From 2008, the country has experienced a rapid deterioration in the public finances, a collapse in the housing market and construction sector, and a liquidity crisis for the banking system. ${ }^{27}$ The recent 'bursting' of national financial and housing bubbles, coupled with the government's 2008 decision (endorsed by the EU) to State guarantee all banking debt, has meant that the crisis in Ireland is particularly severe. In March 2009, the government unilaterally introduced an emergency budget, introducing pay cuts for all public servants. In December 2009, attempts to negotiate a new social pact collapsed and that month's budget again cut public sector pay. In March 2010, with the social partnership process moribund, the public sector unions and employers concluded a new four-year Public Service Agreement (the 'Croke Park Agreement'), ${ }^{28}$ under which it was agreed to protect public sector pay levels in exchange for a reduction in employee numbers and a substantial commitment to organisational reform. In November 2010, the Irish government accepted the terms of an IMF-EU rescue package, outlined a four-year austerity plan, and, in the December budget, introduced $€ 6$ billion of tax increases, new charges and levies and severe welfare and public spending cuts (including a cut in the minimum wage). A general election in early-2011 brought a new coalition government to power, which has committed to carrying out the terms of the bail-out package. The 2011 budget introduced a range of further austerity measures (including further levies and charges and further cuts to public spending).

\section{The Memorandums of Understanding and Labour Law Reform}

As noted above, the Greek government agreed, as a precondition for receiving bailout funds, to the adoption of an austerity program, the exact terms of which were provided for in the First MoU signed between the Greek government and Troika in May 2010 and the Second MoU concluded in February 2012. ${ }^{29}$ Both MoUs contain a complex set of internal policy provisions relating to fiscal consolidation that focus on both the public and private sectors. The MoUs also, however, address 'structural reforms', many of which are aimed at a restructuring of the labour market. The MoUs are premised on the belief that the chronic 'competitiveness deficit' of the Greek economy can be dealt with through 'internal devaluation'; through a reduction in labour costs to be achieved, not only by wage cuts, but also by imposing general restrictions on labour rights. In order to achieve the required internal devaluation, particularly in the context of the (still) relatively heavily regulated nature of the Greek industrial relations system, the MoUs prescribe a number of legislative reforms in a strikingly detailed manner. In fact, the reform provisions (especially those relating to the labour market) are so detailed that the framework laws implementing them into

\footnotetext{
${ }^{26}$ Doherty (2011), op cit $n 22$ supra.

${ }^{27}$ K. O' Kelly, 'The End of Social Partnership in Ireland?', (2010) 16(3) Transfer: European Review of Labour and Research 425.

${ }_{28}^{28}$ Available at http://per.gov.ie/croke-park-agreement/ (accessed 21 May 2012).

${ }^{29}$ The 2010 and 2012 Memorandums of Understanding and all other relevant documents relating to Greece's bail-out are available [in English] at:

http://www.minfin.gr/portal/en/resource/contentObject/contentTypes/genericContentResourceObject,fil eResourceObject,arrayOfFileResourceTypeObject/topicNames/economicPolicyProgram/pageNumber 11/resourceRepresentationTemplate/contentObjectListAlternativeTemplate (accessed 21 May 2012).
} 
the national legal order translate them more-or-less automatically into domestic statutory provisions. So, Article 1 para. 6 of framework law 4046/2012, implementing the Second Memorandum, provides that the MoU clauses relating to labour market reform constitute directly applicable rules. Both Memorandums, therefore, have resulted in far-reaching legislative reforms in the labour market, which, as it will be argued below, are neither occasional nor partial.

The Irish MoU, dated December $12010,{ }^{30}$ unsurprisingly focuses on measures relating to fiscal consolidation and financial sector reforms. However, the MoU similarly addresses 'structural reforms' relating to the labour market. The 2010 agreement pledged a reduction in the national minimum wage of approximately $11.5 \%$, which was implemented by the government in that year's budget, but was reversed by the new government, following negotiations with the Troika in May $2011 .^{31}$ The most significant pledge, however, for the purposes of this article, was to commission an independent review of the Registered Employment Agreement (REA) and Joint Labour Committee (JLC) arrangements, with terms of reference and followup actions to be agreed with the Commission. This review was to be carried out in order to ensure there were no distortions of wage conditions across sectors associated with the presence of sectoral minimum wages in addition to the national minimum wage. It is noteworthy that, by contrast with the Greek case, little in terms of legislative reform was demanded by the Irish MoU. The explanation for this, undoubtedly, reflects heavily the comparatively light nature of Irish labour law regulation. As noted, where legislation exists, it focuses almost exclusively on providing a floor of minimum rights for individual workers. Statutory provisions supporting collective bargaining are almost non-existent. Thus, bargained standards that exceed statutory minima (in terms of pay, working time, etc) are either achieved by trade unions through the deployment (or threat) of industrial action, in the public sector by virtue of the (legally non-binding) Croke Park Agreement, or in sectors covered by EROs or REAs; the last mentioned being the one area where the Troika did demand government action.

\section{The Legislative Response}

\section{A. Greece}

Since the beginning of 2010, significant changes have been made to worker protection laws in Greece. The laws that have been enacted, implementing the provisions of the MoUs, are based on the assumption that, as existing labour legislation constituted the principal obstacle to the competitiveness of the Greek economy, the basic protective labour regulation architecture should be dismantled. In

\footnotetext{
30 The $2010 \mathrm{MoU}$ and all subsequent documents relating to Ireland's bail-out are available at http://www.finance.gov.ie/viewdoc.asp?DoclD=6856 (accessed 21 May 2012).

31 ibid, MoU May 2011.
} 
particular, the underlying logic of the relevant statutes is that labour costs, especially wage costs, constitute the determining factor of an economy's competitiveness. ${ }^{32}$ Consequently, the measures taken to depress not only wages, but labour standards as a whole, should lead to enhanced Greek competitiveness. ${ }^{33}$ Thus, in line with the 'internal devaluation' logic, the recently adopted legal provisions regarding 'labour market regulation' aim to dismantle core elements of the Greek industrial relations system, which were intended primarily for the protection of workers. ${ }^{34}$

\section{i. Minimum Wages and Wage Setting Mechanisms}

As noted, the NGCA concluded periodically between the union and employer representative bodies determines the obligatory minimum levels of pay, and minimum terms of employment, applied throughout Greece. Despite the crisis, in 2010, the social partners were able to conclude a new NGCA which set the obligatory minimum wages to be applied until the end of 2012. However, the implementation of the terms of the Second MoU completely set aside both the preceding national social dialogue and the binding agreement of the social partners. The Second MoU requires, first, that the minimum wages established by the NGCA are to be reduced by $22 \%$ compared to the level of 1 January 2012, while for young workers (those aged below 25), the wages established by the NGCA are to be reduced by $32 \%$. Secondly, clauses in the law and/or in collective agreements that provide for automatic wage increases, including those based on seniority, are to be suspended until the unemployment rate falls below $10 \% .{ }^{35}$ Thirdly, by the end of July 2012, a timetable for an overhaul of the NGCA will be prepared which shall aim at replacing the wage rates set in the NGCA with a statutory minimum wage set by the government, in consultation with social partners. ${ }^{36}$

In addition to their obvious harshness, the above measures clearly infringe collective autonomy since they intervene in, and alter to the detriment of the worker, the outcomes of national social dialogue, as well as the content of concluded CAs. Furthermore, it is obvious that the legislative responses to the demands of the MoUs aim at restricting the scope of collective bargaining, by replacing collectively agreed working standards with binding minima set by law.

\footnotetext{
${ }^{32}$ Milios and Sotiropoulos (2010), op cit $\mathrm{n} 14$ supra.

${ }^{33}$ A. Supiot, 'Law and Labour. A World Market of Norms?', (2006) 39 New Left Review 109. It is interesting to note that, despite the undoubted 'deficit' of the Greek economy's competitiveness, real unit labour costs in Greece have decreased over the last 50 years; see L. Zisimopoulos, G.

Economakis and P. Polychroniou, 'Greek Industrial Relations and the Economic Crisis' (paper delivered at the Industrial Relations in Europe Conference (IREC), Barcelona, Spain, 1-2 September 2011). Therefore, the claimed cause-and-effect relationship between labour costs and national competitiveness, deemed to be the main cause of the 'Greek crisis', has been contested; see also Milios and Sotiropoulos (2010), op cit $\mathrm{n} 14$ supra.

${ }^{34}$ For the purpose of this article, our focus is on the provisions of the recently adopted statutes affecting collective labour rights. Nevertheless, it is important to note that a number of provisions striking at the core of individual labour rights have also been introduced as part of the bail-out requirements; for example, provisions that reduce compensation for dismissal, that facilitate collective dismissals, that reduce overtime pay, and that reduce both the salaries and numbers of public sector employees. It should be acknowledged that it is only by considering these provisions in combination, and in interaction with each other, that the full extent of the deregulation of the entire Greek labour law system can be appreciated.

${ }^{35}$ At the time of writing, the Greek unemployment rate stands at approximately $21 \%$.

${ }^{36}$ Provision included in the $2012 \mathrm{MoU}$ on Specific Economic Policy Conditionality.
} 


\section{ii. The Abolition of the 'Favourability Principle'}

The legislative reform that most severely infringes upon collective autonomy has been the abolition of the favourability principle, formerly a fundamental organising principle of the Greek labour law system. Article 37 para. 5 of law 4024/2011, implementing the First MoU, provides that enterprise-level CAs will prevail (in all cases) over sectoral CAs, even where the clauses contained in the former are less favourable to the employee than those contained in the latter. Furthermore, Article 37 para. 1 of the same law provides that any group of workers representing threefifths $(60 \%)$ of those employed in the enterprise may conclude enterprise level CAs, a power traditionally reserved only to legally formed trade unions. In other words, the law allows groups of workers which possess neither negotiating nor 'formal' representative power to conclude enterprise level CAs, which can derogate from those at sectoral level.

The clear goal of these reforms is to promote and reinforce enterprise-level CAs, whilst marginalising sectoral CAs. This is likely to have a major impact on the regulation of industrial relations to the detriment of workers, given that, in almost all European systems of collective autonomy, collective bargaining and collective agreements at sectoral level play a dominant role. ${ }^{37}$ In particular, sectoral CAs have proven to be the most appropriate and effective mechanism in terms of laying down conditions of employment, especially wage rates, primarily because they are able to homogenise to a large extent wages (and, indeed, other working standards), thus taking them out of competition. ${ }^{38}$ At the same time, sectoral-level bargaining significantly reduces the danger of trade unions being manipulated by, or subordinated to, the employer, a danger which is more clearly present at enterpriselevel. Nonetheless, sectoral CAs are to be marginalised in Greece under the new legal regime, the aim of which seems to be the imprisonment of collective bargaining structures within the limits of the enterprise, where labour is weaker numerically and in terms of negotiating power.

\section{iii. Changes in the Arbitral Regime}

In accordance with the terms of the Second MoU, arbitration shall now take place only when agreed by both employee and employer groups. Under the previous legal regime (Article 16 of law 1876/1990), trade unions had the right to unilaterally resort to arbitration, in cases where they accepted, but the employer rejected, a mediator's proposition. Moreover, henceforth resort to arbitration may only take place in respect of issues regarding the basic wage (and not in relation to other forms of remuneration or working conditions). Again, under the previous regime, the

\footnotetext{
${ }^{37}$ B. Bercusson, 'European Labour Law and Sectoral Bargaining', (1993) 24 Industrial Relations Journal 257; M. Keune, 'Derogation Clauses on Wages in Sectoral Collective Agreements in Seven European Countries', Eurofound (2010) available at: http://www.eurofound.europa.eu/pubdocs/2010/87/en/2/EF1087EN.pdf (accessed 21 May 2012). ${ }^{38}$ ibid.
} 
arbitration process could be concerned with any issue which formed part of the subject-matter of collective bargaining. Finally, Article 51 of law 3871/2010, implementing the provisions of the First MoU, provides that arbitration awards are not allowed to grant, in any way, wage increases for the year 2012 (this has been the case, in practice, since 2010). In general, the demands of the MoUs regarding arbitration aim at restricting its role, thus setting aside a major component of the collective bargaining mechanism outlined in the Greek Constitution (Article 22(2)). ${ }^{39}$ It is, thus, once again apparent that the terms of the MoUs seek to limit the influence of the social partners - and especially that of the trade unions - on labour market regulation.

The Second MoU also requires that 'collective agreements which have expired will remain in force for a maximum period of three months' and that 'if a new agreement is not reached, after this period remuneration will revert to the basic wage'. ${ }^{40}$ The implications of this provision must be assessed jointly with the changes in the arbitral regime described above. When a CA expires (including the NGCA) the social partners must reach a new agreement within three months. ${ }^{41}$ During this period, it will clearly be in the employers' interests not to reach agreement given that, in the event that the negotiations fail, the wages of the employees concerned will revert to the basic wage. As the workers cannot now resort to arbitration without the employer's consent, and such consent will be, of course, unlikely to be forthcoming within the three-month period, the most likely outcome of such a scenario is that the majority of workers will relatively quickly see their pay drop to the level of the basic wage.

Allied to all this is clear evidence that the labour law policies currently being applied seem to be promoting a transition from collective to individual bargaining. Since the beginning of 2011, more and more Greek enterprises have concluded individual contracts of employment, ${ }^{42}$ which provide for lower wages and inferior conditions of employment than those contained in the previously applicable CAs. Needless to say, individual bargaining, in the context of an economic recession, equates to a severe infringement on the right to negotiate, since in most such cases the terms of employment are simply imposed by the employer. It should be remembered, too, that the sharp wage decline has been accompanied by rising unemployment, a drop in social security contributions and a consequent deterioration in the financial status of the Greek social insurance system.

\footnotetext{
${ }^{39}$ A. Kazakos, The Arbitration of Collective Disputes of Interests according to the Law 1876/90 (Sakkoulas, 1998) [In Greek].

${ }^{40}$ Under the previous legal regime the regulatory terms of a collective agreement remained in force for a period of six months after its expiration.

${ }^{41}$ The Second MoU also contains provisions shortening the duration of already concluded CAs.

42 According to the Hellenic Labour Inspectorate's (S.EP.E) data, from 14 February 2012 to 31 March 2012, 7,825 enterprises have concluded individual employment contracts with 33,133 employees, providing for average pay cuts of $22 \%$. S.EP.E press release 23 April 2012. See, for example, http://www.tovima.gr/finance/article/?aid=454394 (accessed 21 May 2012).
} 


\section{B. Ireland}

In Ireland, as noted, much less has been demanded in terms of reforming labour market regulation. The review of the ERO and REA systems was published in May 2010 and recommended reform, rather than abolition. ${ }^{43}$ Before the government took any action, events were somewhat overtaken when the Irish High Court declared that the legislation allowing the imposition of terms and conditions of employment by means of an ERO was unconstitutional. ${ }^{44}$ The decision, predictably, was welcomed by employer groups, with many calling for the abolition of the ERO system in its entirety. ${ }^{45}$ Trade unions, meanwhile, expressed concerns that, following the ruling, workers in sectors covered by EROs, would have their terms and conditions of employment downgraded. ${ }^{46}$ However, the Minister for Jobs, Enterprise and Innovation has moved swiftly to pledge new legislation to re-establish, with significant reforms, the ERO/REA systems; the result is the Industrial Relations (Amendment) (No 3) Bill 2011.

It is noticeable that the proposed legislation does not take up the recommendation of the ERO/REA review group, set up in accordance with the MoU, to establish a welldesigned framework where collective bargaining (within the meaning of Article 28 of the Charter of Fundamental Rights of the European Union and relevant International Labour Organisation - ILO - Conventions) ${ }^{47}$ could take place. However, it should be acknowledged that the Irish government, with the consent of the Troika, has chosen to re-establish the ERO/REA systems, rather than simply abolish them. Nonetheless, the discernible regulatory trend that can be identified in this case is one that seeks a move away, first, from prioritising the role of the social partners in negotiating and policing regulation of terms and conditions of employment and, secondly, moving towards the establishment of statutory minimum standards and away from bargained terms and conditions of employment.

First, in a number of crucial ways, the Bill either explicitly or implicitly sanctions an imposition of statutory minimum standards. It explicitly prohibits, for example, EROs from providing for premium pay rates for Sunday working, as was the case

\footnotetext{
${ }^{43} \mathrm{~K}$. Duffy and F. Walsh, Report of Independent Review of Employment Regulation Orders and Registered Employment Agreement Wage Setting Mechanisms (available at http://www.djei.ie/publications/employment/2011/Report ERO REA.pdf; accessed 21 May 2012). ${ }^{44}$ John Grace Fried Chicken Ltd \& Ors v Catering Joint Labour Committee \& Ors [2011] IEHC 277. For full discussion of this case see M. Doherty, 'Battered and Fried? Regulation of Working Conditions and Wage-Setting after the "John Grace” Decision', (2013, forthcoming) Dublin University Law Journal.

${ }^{45}$ See, for example, "IBEC Welcomes High Court Ruling on JLCs" (http://www.ibec.ie/IBEC/Press/PressPublicationsdoclib3.nsf/vPages/Newsroom ibec-welcomes-highcourt-ruling-on-jlcs-07-07-2011? OpenDocument; accessed 21 May 2012).

46 "UNITE Demands Emergency Legislation for Low Paid Workers after JLC Court Ruling" (http://www.unitetheunion.org/regions/ireland/news from ireland/unite calls for emergency legi.asp x; accessed 21 May 2012).

47 See C98, The Right to Organise and Collective Bargaining Rights Convention 1949; C154, The Collective Bargaining Convention 1981; and also the Collective Bargaining Recommendation of 1951 (No 91).
} 
previously. ${ }^{48}$ The Bill lists a number of factors to be considered by JLCs when formulating an ERO (e.g. consideration of the appropriateness of fixing a minimum hourly rate of pay that is higher than the existing statutory minimum wage; the wage levels in comparable sectors in other countries) and also sets restrictions on establishing pay scales that seek to go beyond the basic rate in order to reflect skills and experience. ${ }^{49}$ As a result, in an echo of the Greek case, what emerges in terms of remuneration under the reconstituted ERO system may well approximate the provisions of the minimum wage legislation.

The Bill also contains 'inability to pay' provisions, allowing employers to seek temporary derogations from the sector-level minimum pay and conditions set by EROs on grounds of financial difficulty. ${ }^{50}$ These individual exemptions, which can be granted to employers for up to two years and, in some cases, without the agreement of employees, may well undermine the ERO/REA systems entirely, by creating an uneven playing field and allowing employers with exemptions to undercut their competitors. The legislation also confers a wide discretion on the Minister to accept or reject a proposed ERO or REA. It has been argued that the legislation, in this respect, lacks proportionality by giving the Minister an outright veto, rather than an oversight role. ${ }^{51}$ Finally, given the weak constitutional and statutory protection afforded trade unions under Irish law, it is not at all clear that employers that refuse to recognise trade unions for bargaining purposes will simply accept the imposition of terms and conditions of employment (under EROs) negotiated by committees on which trade unions are represented. It is also likely that increasing challenges to the 'representativeness' of the parties to an REA may occur, from employers who are openly hostile to trade union involvement in standard-setting processes. ${ }^{52}$

\section{Social Policy, Labour Rights and the 'Competition' Principle}

Our analysis of the provisions of the Greek and Irish MoUs, as they affect the respective labour law regimes, clearly shows that the demands of the Troika (which includes, of course, the European Commission) are directed towards reducing the influence of trade unions on labour market regulation and reducing the scope for collectively bargained employment standards, in favour of legally binding minima. The role of the social partners (and, especially, the trade unions) in enforcing and policing employment standards is also reduced.

At first glance, such demands seem to run counter to recent developments in European law. Article 11 of the European Convention on Human Rights (ECHR), which guarantees the right to form and join trade unions, has lately been the subject

\footnotetext{
48 Industrial Relations (Amendment) (no 3) Bill 2011, s 12.

49 ibid.

${ }^{50}$ Industrial Relations (Amendment) (no 3) Bill 2011, s 14.

${ }^{51}$ Doherty (2013) op cit $n 44$ supra.

52 The Bill requires the parties to a REA (on both the union and employer sides) to demonstrate that they are 'substantially representative' of employers and employees in the sector in question (Industrial Relations (Amendment) (no 3) Bill 2011, s 5).
} 
of a number of significant applications before the European Court of Human Rights (ECtHR). In Demir and Baykara v Turkey ${ }^{53}$ the ECtHR held that Article 11 encompasses a right not to have prohibitions imposed on the freedom of trade unions to engage in collective bargaining. The Court seemed to suggest that the absence of legislation necessary to give effect to provisions of international law (in particular ILO Conventions) protecting collective bargaining rights might be in breach of the ECHR. ${ }^{54}$ Following the entry into force of the Treaty of Lisbon in 2009, Article $6(3)$ of the new Treaty on European Union (TEU) states that 'fundamental rights, as guaranteed by the (ECHR) and as they result from the constitutional traditions common to the Member States, shall constitute general principles of the Union's law'. ${ }^{55}$ Moreover, the Treaty of Lisbon confirmed the Charter of Fundamental Rights as having the same legal value as the EU Treaties. ${ }^{56}$ Article 28 of the Charter provides for the right of trade unions to negotiate and conclude collective agreements and, in cases of conflicts of interest, to take collective action to defend their interests, including strike action. Furthermore, Article 152 of the Treaty on the Functioning of the EU (TFEU) states that the Union 'recognises and promotes the role of the social partners' at Union level, whilst the Treaty grants the social partners at both Union and Member State level unique and privileged roles in the legislative process, underlining the importance that the Union gives to collective autonomy as a core self-regulating mechanism of industrial relations. ${ }^{57}$ The Union's commitment in the Treaties to protecting collective labour rights and promoting the rights of the social partners can be placed in the broader context of the affirmation and reinforcement in the Treaties of the Union's social dimension. Article 3(3) TEU, for example, states that the Union shall work to establish a 'social market economy, aiming at full employment and social progress' and it shall also 'promote social justice'.

In this regard, the MoUs and the (proposed/) statutes implementing their provisions, appear to conflict with the goals outlined in the Treaties and more generally to clash with the basic principles of the European social model. ${ }^{58}$ However, we argue that this apparent contrast is, in fact, illusory and that the logic of the reforms demanded is fully in conformity with the norm that governs the EU legal order. Moreover, we argue that the deregulatory thrust of the Greek and Irish reforms are perfectly consistent with the organising principle of the EU as it has been established by the EU institutions and developed mainly by the CJEU; this principle being 'competition'. This main principle thus defines the rules of EU governance of industrial relations, rules by which the MoUs seek to have the Greek and Irish labour law regimes abide.

\footnotetext{
${ }^{53}$ Application No 34503/97, 12 November 2008.

${ }^{54}$ See K. Ewing and J. Hendy, 'The Dramatic Implications of Demir and Baykara', (2010) 39(1) Industrial Law Journal 2.

${ }^{55}$ Art 6(2) TEU, of course, states that the Union 'shall accede to the (ECHR)'; see L. Pech, and X. Groussot, 'Fundamental Rights Protection in the EU Post Lisbon Treaty' (2010) (available at: http://ssrn.com/abstract=1628552).

${ }_{57}^{56}$ A. Stergiou, 'The Social Europe in the Lisbon Treaty', (2011) Labour Law Review 1 [in Greek]. 57 See Articles 153-155 TFEU.

${ }^{58}$ On which, see J. Wickham, 'The End of the European Social Model Before it Began?', (2002, Employment Research Centre, Trinity College Dublin; available at http://www.tcd.ie/ERC/observatorydownloads/Social\%20Model.pdf; accessed 21 May 2012); J. Grahl and P. Teague, 'Is the European Social Model Fragmenting?', (1997) 2(3) New Political Economy 405.
} 


\section{A. The Memorandums of Understanding and the 'Grundnorm' of the EU Legal Order}

Perhaps the most common misunderstanding of European integration is that the process of establishing a single market is realised through the minimisation, or even the prohibition, of State intervention, on the basis that the free market will regulate itself fairly ${ }^{59}$ On the contrary, the integrated market is principally promoted by a particular form of governance, and the process of integration is basically characterised by recourse to regulatory institutions, which exist to dictate certain policies, in order to achieve certain goals ${ }^{60} \mathrm{~A}$ mode of governance is thus established, if not imposed, which facilitates and enhances competition, guaranteeing in this way the 'free' function of the market. This mode of governance, which is regulatory and, consequently, deeply interventionist, is instituted either through direct EU legislation or through the decisions of the CJEU. The Court, it is uncontroversial to note, has gradually broadened the scope of the free movement provisions, granting them the status of fundamental rights, in order to establish the EU legal order and to extend EU supervision over national legal orders. This expansive interpretation has led to a spill-over of market integration rules into almost all areas of national law and, consequently, many national social rights and policies have been challenged as being contrary to free movement provisions and, as a result, have been revised or even rejected. ${ }^{61}$

This march of events cannot be considered to be random. In order for a market rationale to be established, competition shall no longer refer only to the economic field, but shall also enter into the legislative sphere, becoming the latter's organising principle. ${ }^{62}$ In other words, "competition" becomes the main principle of policymaking, setting in motion a regulatory mechanism that would reject any policy that might harm competition and would only allow through its filter policy proposals' that conform with its logic. ${ }^{63}$ Through this mechanism of rejection or approval of policies, of potential rules, 'competition' itself is rendered a general norm. In other words, any regulatory policy choice is assessed in terms of its ability to favour this specific model of market governance. 'Competition' appears to function as the 'Grundnorm', ${ }^{64}$

\footnotetext{
${ }^{59}$ P. Dardot and C. Laval, La Nouvelle Raison du Monde. Essai Sur la Société Néolibérale. (2010, La Découverte), 10.

60 Indeed, it has been argued that 'European governance' is better understood as a type of 'neoliberal "governmentality", i.e. a regime of normative and dispositional power involving the production of certain "truths" about the people and things to be governed'; C. Shore, "European Governance" or Governmentality? The European Commission and the Future of Democratic Government' (2011) 17(3) European Law Journal 287, 289.

${ }^{61}$ M. Maduro, We the Court: The European Court of Justice and the European Economic Constitution (Hart, 1998), 16-25; M. Maduro, 'Striking the Elusive Balance Between Economic Freedom and Social Rights in the EU', in P. Alston (ed), The EU and Human Rights (Oxford University Press, 1999) at 449; Stergiou, (2011), op cit $\mathrm{n} 56$ supra.

${ }^{62}$ Supiot (2006), op cit $\mathrm{n} 33$ supra.

${ }^{63}$ T. Papadopoulos and A. Roumpakis, 'Re-embedding the Labour-Capital Relation in the European Union: the "Meta-regulated" European Social Space and the role of the European Court of Justice (ECJ) Rulings', (paper delivered at the Industrial Relations in Europe Conference (IREC), Oslo, Norway, 8-10 September 2010).

${ }_{64}$ The Grundnorm, the basic norm, in Kelsen's theory of law constitutes the highest law from which all derived norms (including the Constitution) draw their validity; $\mathrm{H}$. Kelsen, Pure Theory of Law (trans. M. Knight, University of California Press, 1978), 50. The Grundnorm is a meta-legal norm, which itself
} 
for it constitutes the precondition for validity of all derived rules, a meta-legal norm that has not been produced by a constituent power and upon which the entire legal system is based. Legislative reforms are thus dictated by the basic norm of competition and the relevant rules are envisaged and applied in order to organise, to facilitate and to stimulate competition itself, and it is exactly this idea that rules are necessary for the proper functioning of competition that lies at the heart of this new model of governance. ${ }^{65}$

The basic norm of competition governs the judicial sphere also. By 'govern' we do not simply refer here to the influence of a dominant ideology on judicial interpretation, but to the perception of competition as the 'Grundnorm' upon which the whole regulatory system is founded. ${ }^{66}$ In this framework, any potential multiplicity (or conflict) of values is not taken into consideration ${ }^{67}$ and the balancing of conflicting rights is replaced by the application of one vigorous rule, that which best serves the functioning of the 'competition norm' ${ }^{68}$ This has been exactly the structure of the CJEU rulings in the 'Laval Quartet' series of case law. In these widely known cases, the CJEU was called upon to deliver its judgment with regard to disputes that arose from the collision of an economic freedom with a trade union right. Instead of framing the issue as involving the confrontation of two opposed rights of equal value, ${ }^{69}$ the Court organised its reasoning on the basis of the application of a legal rule. Thus, the premise which prevailed in the Court's judgment was the binary logic of 'rule exception', ${ }^{70}$ where the economic freedom was considered to be 'the rule', whilst the collective labour right was identified as 'the exception'. An ideological hierarchy of values (where economic freedoms lie over and above social rights) was thus transformed, through the Court's reasoning, into a prescriptive supremacy. ${ }^{71}$

As a result, on the basis of the application of the basic norm, legislative initiatives are accepted to the extent that they enhance market competition; either by imposing rules which promote, or by dismantling regulatory systems which hinder, such competition. Market economy rules are considered to be a stable and unchangeable element, a standard to which national legal orders should adjust, with the only question left to the political authorities being how to manage the reforms necessary

has not been produced by a constituent power. In fact, it is a 'hypothetical foundation', a 'mental presupposition' that does not describe something existing, but the validity of which is presupposed in order to explain the normative character, the unity, and the autonomy of the whole legal system. On these points see A. Kalyvas, 'The Basic Norm and Democracy in Hans Kelsen's Legal and Political Theory', (2006) 32 Philosophy \& Social Criticism 573, 576-580.

65 Dardot and Laval (2010), op cit $\mathrm{n} 59$ supra, 11.

${ }^{66}$ Supiot (2006), op cit $\mathrm{n} 33$ supra.

67 Maduro (1998), op cit n 61 supra,16-25.

${ }^{68}$ Supiot talks of a 'metajuridical principle that must be imposed on every aspect of social life', (2006) op cit $\mathrm{n} 33$ supra, 115.

${ }^{69}$ B. Bercusson, Collective Action and Economic Freedoms Before the European Court of Justice (ETUI, 2007); A.C.L. Davies, 'One Step Forward, Two Steps Back? The Viking and Laval Cases in the ECJ', (2008) 37(2) Industrial Law Journal 126; E. Ales and T. Novitz (eds), Collective Action and Fundamental Freedoms in Europe: Striking the Balance (Intersentia, 2010).

${ }^{70}$ R. Dworkin, Taking Rights Seriously (Duckworth, 1978), 22-28; P. Schlag, 'Rules and Standards', (1985) 33 UCLA Law Review 379.

${ }^{71}$ E. Achtsioglou, 'What Future for Trade Union Rights after the Recent Case Law of the European Court of Justice?', (paper delivered at the Industrial Relations in Europe Conference (IREC), Oslo, Norway, 8-10 September 2010). 
to adjust to these 'objective' standards in national legal systems. ${ }^{72}$ It is precisely, then, this process of 'necessary adjustment' to the rules set out by the 'competition norm', which leads national legislatures to compete against each other.

Consequently, even 'national legislative models are today treated as so many products in competition with each other in the world market of norms'. ${ }^{73}$ This is best exemplified in the field of industrial relations, where national labour law systems compete against each in terms of their impact on economic competitiveness. It is from this competition of laws that the danger of a 'race to the bottom' in respect of terms and conditions of employment emerges.

Thus, Ireland, with its lightly regulated labour market ${ }^{74}$ and meagre protection for collective bargaining, is required only to 'review' but one aspect of its labour legislation; although, notably, one of the few aspects that provides for bargained standards, which impede the free workings of market competition. ${ }^{75}$ Even here, however, in April 2012, the Troika insisted on two amendments to the proposed Irish legislation; first, to allow employers seeking temporary 'inability to pay' exemptions to get two consecutive exemptions within the overall two-year limit, where necessary to safeguard employment and, secondly, to ensure the process for granting a variation or cancellation of a REA is conducted in a timely manner. ${ }^{76}$ Both amendments, whilst relatively minor in and of themselves, represent support for a minimalist position in terms of the extent to which future EROs/REAs might offer bargained terms and conditions of employment in excess of statutory minima. However, what is perhaps more significant is the extent to which labour market regulation is to be 'micromanaged' by the EU institutions; even in relatively 'neo-liberal' Ireland, ${ }^{77}$ the implementation of the dominant norm of 'competition' must be closely monitored.

Unsurprisingly, then, Greece must go considerably further and dismantle a range of protections for trade union rights. Under Greece's new labour law regime, collective autonomy and social dialogue are imprisoned within a legislative framework, which is to be directly supervised by the courts. ${ }^{78}$ The law directly restricts collective autonomy ${ }^{79}$ and the role of arbitration, for the law is the mechanism responsible for guaranteeing the respect of the 'competition norm'. The regulation of labour relations is to be organised on the basis of the maxim that not only wages, but also general

\footnotetext{
72 Supiot (2006), op cit n 33 supra.

73 ibid, 112. Supiot notes that the World Bank, in its annual 'Doing Business' reports, demonstrates a clear preference for common law legal systems (such as those of Ireland, the UK and the USA), which are less likely to impose 'rigidities' on firms' hiring practices.

${ }^{74}$ In the World Bank's Doing Business Report 2012, Ireland is number 10 in the 'rankings on the ease of doing business' list; Greece is number 100 (available at http://www.doingbusiness.org/reports/global-reports/doing-business-2012; accessed 21 May 2012).

${ }^{75}$ It is interesting to note that, whilst reforms of bargaining mechanisms are deemed essential, the Troika seemingly raised no objection to the reversal in the cut to the statutory minimum wage implemented in 2011 by the new coalition government.

${ }^{76} \mathrm{http}: / /$ www.finance.gov.ie/viewdoc.asp?DocID=7222\&CatID=78\&StartDate=1+January+2012 (accessed 21 May 2012).

77 G. Boucher and G. Collins, 'Having One's Cake and Being Eaten Too: Irish Neo-liberal Corporatism', (2003) 61(3) Review of Social Economy 295.

${ }^{78}$ L. Azoulai, 'The Court of Justice and the Social Market Economy: the Emergence of an Ideal and the Conditions for its Realisation', (2008) 45 Common Market Law Review 1335; A. Kazakos, Collective Labour Law Vol. I (Sakkoulas, 2009), 54-55 [in Greek].

${ }^{79}$ Article 13 of law 3899/2010.
} 
terms and conditions of employment, should be reduced in order to become competitive within the integrated market.

\section{Conclusions}

We have argued that the reforms demanded of Greek and Irish labour law by the Troika, in exchange for financial backing, have been aimed squarely at reducing the scope for collectively bargained labour standards and social partner monitoring thereof, and concentrate on ensuring only the enforcement of legally binding minimum standards of pay, and other terms and conditions of employment. We have also argued that this is perfectly consistent with the underlying norm dominating EU governance processes, particularly in the sphere of labour market regulation, and most recently visible in the 'Laval Quartet' judgments of the CJEU. ${ }^{80}$

The issues discussed in this article are, of course, hugely significant for workers, employers and other labour market actors. ${ }^{81}$ However, they also touch on fundamental questions about the future direction of economy and society at both domestic and EU level. First, bargained standard-setting is of particular pertinence to low-paid sectors where vulnerable workers tend to be concentrated. Such sectors are often characterised by low levels of trade union organisation, and relatively high numbers of migrant workers, young people, and part-time and casual workers, with little or no individual bargaining power, and who are, consequently, more amenable to succumbing to pressure to accept inferior working terms and conditions. ${ }^{82}$ As Duffy and Walsh note, for 'unskilled workers in a large European labour market with free mobility of labour it is unlikely that the market mechanism will provide... adequate protection'. ${ }^{3}$ In such a labour market, the danger of competition in terms of continually degrading working conditions is ever present, since enterprises established in States with different level of workers' protection can operate in the same integrated market. Removal of trade union and collective bargaining protections would be likely to have seriously detrimental social consequences for many already low-paid workers, and would disproportionately affect certain categories of workers, such as migrants and females.

Secondly, it has been noted that the jurisprudence on collectively bargained standards 'has the potential to alienate from the single market and the EU a segment

\footnotetext{
${ }^{80}$ It had been suggested that the (post-Lisbon) legally binding status of Article 28 of the Charter of Fundamental Rights might encourage the CJEU to adopt a different approach to the protections to be afforded collective bargaining under EU law; see S. Morano-Foadi and S. Andreadakis, 'Reflections on the Architecture of the EU after the Treaty of Lisbon: the European Judicial Approach to Fundamental Rights', (2011) 17(5) European Law Journal 595. Recent judgments from the CJEU, however, indicate this to be unlikely; see Case C-271/08, Commission v Germany, judgment of 15 July 2010, where the CJEU held that the fundamental rights to bargain collectively, and to autonomy in collective bargaining, could not justify the awarding of public contracts, on the basis of selection criteria agreed under collective agreements, in violation of EU public procurement rules.

81 See S. Sciarra, 'Notions of Solidarity in Times of Economic Uncertainty', (2010) 39(3) Industrial Law Journal 223.

82 These are precisely the sectors (retail, cleaning, hotels) covered by the Irish JLCs.

${ }^{83}$ Duffy and Walsh (2010), op cit n 43 supra, 48.
} 
of public opinion, workers' movements and trade unions, which has been over time a key supporter of economic integration, ${ }^{84}$ It is contended here that it is not simply workers' movements that are disconcerted by a potential 'race to the bottom' in terms of working terms and conditions, and social protection, but that the current economic climate has engendered a much more widespread public suspicion of greater market integration measures at EU level, which for many, is 'code for dismantling social rights protected at national level'. ${ }^{85}$ In the initial common market project (as outlined in the Treaty of Rome) it was a widespread belief that the internal market would automatically lead to social progress and to the harmonisation of national social legislation. ${ }^{86}$ However, the policy of the Union's non-intervention in the social field has evidently been traced out. ${ }^{87}$ In Greece and Ireland, the role played by EU institutions (especially the Commission) in the context of the economic crisis and, in particular, the terms of the economic support packages have clearly damaged public support for the EU project. ${ }^{88}$

Finally, we return to the issue of labour rights. It seems apparent from the analysis in this article that the protection and promotion of collective labour rights in the EU legal order cannot be achieved through the mere recitation of social rights in a catalogue of fundamental rights, ${ }^{89}$ even if this catalogue is to be legally binding. What it demands is a political restructuring of EU policies and institutions, for, without an expansion of the EU's competences within the social field, any social objective will remain simply declaratory. ${ }^{90}$ EU social policy should no longer be conceived as a functional necessity of economic integration, but as an autonomous competence based on criteria of distributive justice. ${ }^{91}$ Consequently, it is maintained that EU competences in the social policy field need to evolve from the 'regulatory status', where they have been until now, to the 'redistributive status'; for without a substantial budget focusing on redistribution, the EU's social dimension will not be sufficiently prompted. ${ }^{92}$ Such a transition could only be achieved through the reintroduction of control (both political and legal) over competition with a view to enhancing the wellbeing of society; if serving society's interest is still considered to be a valued end in itself.

\footnotetext{
${ }^{84}$ M. Monti, A New Strategy for the Single Market- At the Service of Europe's Economy and Society (Report to the European Commission, 9 May 2010); available at: http://ec.europa.eu/internal market/strategy/docs/monti report final 10052010 en.pdf (accessed 21 May 2012), 68.

85 ibid, 69.

${ }^{86}$ A position clearly expressed in Article 117 of the Treaty of Rome.

${ }^{87}$ B. Bercusson, European Labour Law (Cambridge University Press, $2^{\text {nd }}$ ed, 1999).

${ }^{88}$ See, for example, 'The Callous Cruelty of the EU is Destroying Greece', The Daily Telegraph, 15 February 2012; 'Dislocated and Disillusioned', The Irish Times, 8 October 2011.

${ }^{89}$ Contra B. Ryan, 'The Charter and Collective Labour Law', in T. Hervey and J. Kenner (eds), Economic and Social Rights under the EU Charter of Fundamental Rights (Hart, 2003), at 67.

${ }^{90}$ Azoulai (2008), op cit $\mathrm{n} 78$ supra.

91 Maduro (2009), op cit $\mathrm{n} 61$ supra.

92 Stergiou (2011), op cit n 56 supra.
} 